\title{
Experimental Infection of Danish Landrace/ Yorkshire Crossbred Pigs with Schistosoma japonicum from the People's Republic of China
}

\author{
By A. L. Willingham ${ }^{1,2}$, M. V. Johansen ${ }^{2}$, B. J. Vennervald ${ }^{2}, N . \emptyset$. Christensen $^{2}$ and P. Nansen ${ }^{1}$ \\ ${ }^{1}$ Danish Centre for Experimental Parasitology, The Royal Veterinary and Agricultural University, Frederiks- \\ berg, and the ${ }^{2}$ Danish Bilharziasis Laboratory, Charlottenlund, Denmark.
}

\begin{abstract}
Willingham A. L., M. V. Johansen, B. J. Vennervald, N. Ø. Christensen and P. Nansen: Experimental infection of Danish Landrace/Yorkshire crossbred pigs with Schistosoma japonicum from the People's Republic of China. Acta vet. scand. 1994, 35, 395-400. - This study was undertaken to assess the suitability of Danish Landrace/Yorkshire $(\mathrm{L} / \mathrm{Y})$ crossbred pigs as experimental hosts of a Chinese mainland strain of Schistosoma japonicum. Pigs were exposed to 200,500 or 1000 cercariae and parasite burdens were determined by perfusion after either 8 or 11 weeks. All pigs became infected with onset of faecal egg excretion 6 to 7 weeks following exposure to cercariae. The pattern of faecal egg excretion differed markedly among the individual animals. Gross hepatic pathological lesions of varying degrees were noted in all of the pigs. Schistosome worm recoveries ranged from $1.5-23.4 \%$ of the cercarial exposure dose. Most schistosome eggs recovered from the tissues, expressed as eggs/g tissue, were found in the rectum $(91 \%)$, caecum $(3.1 \%)$ and liver $(5.1 \%)$. The results show that Danish L/Y pigs may serve as appropriate experimental final hosts of the Chinese mainland strain of $S$. japonicum.
\end{abstract}

Animal model; population biology; zoonosis.

\section{Introduction}

Schistosoma japonicum is a zoonotic Asian schistosome which parasitizes a wide range of mammalian hosts. Over a hundred million people are at risk of $S$. japonicum infection, which can cause life-threatening liver and colorectal disease (Mott 1982). Water buffaloes, cattle, pigs, dogs and rodents are considered important reservoir hosts, contributing to the transmission of S. japonicum (Basch 1986, Kumar \& de Burbure 1986, He 1993, Xu et al. 1993). Considering the anatomical, physiological and immunological similarities of man and pig (Swindle 1984, Phillips \& Tumbleson 1986), porcine schistosomiasis japonica may be a relevant model for human $S$. japonicum infection. However, little is known about natural $S$. japonicum infection in pigs and only few experimental studies have been conducted. $\mathrm{Ya}$ son \& Novilla (1984) were able to infect different breeds of pigs with a Philippine strain of $S$. japonicum and obtained some initial information on clinical, gross pathological and histopathological features of the infection. However, Reid \& von Lichtenberg (1977) found that miniature pigs were unsuitable hosts for a Japanese strain of S. japonicum. Normal sized Chinese pigs investigated in a vaccine trial involving a Chinese mainland strain of $S$. japonicum were found to be suitable hosts, although the worm establishment was low (Shi et al. 1993). Further studies are needed to improve our understanding of the host-parasite relationship and the population 
Table 1. Schistosoma japonicum infection of Danish Landrace/Yorkshire crossbred pigs. Details of experimental design and worm recovery from perfusions at 8 or 11 weeks following exposure to 200, 500 or 1000 cercariae/pig.

\begin{tabular}{lcccccccc}
\hline & & & & \multicolumn{3}{c}{ Schistosome recovery } \\
\cline { 6 - 9 } Pig & $\begin{array}{c}\text { Cercarial } \\
\text { dose }\end{array}$ & $\begin{array}{c}\text { Duration of } \\
\text { experiment } \\
\text { (weeks) }\end{array}$ & $\begin{array}{c}\text { Prepatent } \\
\text { period }\end{array}$ & $\begin{array}{c}\text { Number of males/ } \\
\text { females /immatures }\end{array}$ & $\begin{array}{c}\text { Total } \\
\text { number of } \\
\text { worms }\end{array}$ & $\begin{array}{c}\text { Number } \\
\text { of worm } \\
\text { pairs }\end{array}$ & $\begin{array}{c}\text { Worm recovery } \\
\text { percentage }\end{array}$ & $\begin{array}{c}\text { Male/ } \\
\text { Female } \\
\text { ratio }\end{array}$ \\
\hline 1 & 1000 & 11 & 7 & $9 / 16 / 0$ & 25 & 9 & 2.5 & 0.6 \\
2 & 1000 & 11 & 7 & $6 / 9 / 0$ & 15 & 6 & 1.5 & 0.7 \\
3 & 1000 & 11 & 7 & $26 / 36 / 0$ & 62 & 26 & 6.2 & 0.7 \\
4 & 500 & 11 & 7 & $42 / 21 / 0$ & 63 & 21 & 12.6 & 2.0 \\
5 & 500 & 11 & 6 & $92 / 25 / 0$ & 117 & 25 & 23.4 & 3.7 \\
6 & 200 & 8 & 6 & $2 / 2 / 4$ & 8 & 2 & 4.0 & 1.0 \\
7 & 200 & 8 & 7 & $7 / 6 / 2$ & 15 & 6 & 7.5 & 1.2 \\
8 & 200 & 8 & 7 & $7 / 7 / 2$ & 15 & 7 & 7.5 & 1.0 \\
9 & 200 & 8 & 7 & $8 / 1 / 0$ & 9 & 1 & 4.5 & 8.0 \\
10 & 200 & 8 & 6 & $2 / 1 / 4$ & 7 & 1 & 3.5 & 2.0 \\
\hline
\end{tabular}

Table 2. Number and distribution of Schistosoma japonicum tissue eggs (eggs/g tissue, $\%$ distribution) in Danish Landrace/Yorkshire crossbred pigs 11 weeks following exposure to either 500 or 1000 cercariae.

\begin{tabular}{lccccccc}
\hline & \multicolumn{5}{c}{ Schistosome egg counts/g tissue } \\
\cline { 2 - 7 } Pig $^{1}$ & Lung & Liver & Duodenum & Jejunum & Caecum & Colon & Rectum \\
\hline 1 & 0 & 250 & 117 & 17 & 17 & 0 & 19600 \\
2 & 17 & 500 & 33 & 67 & 483 & 17 & 83 \\
3 & 0 & 483 & 0 & 17 & 550 & 0 & 3100 \\
4 & 0 & 917 & 33 & 100 & 467 & 0 & 22583 \\
5 & 0 & 483 & 0 & 0 & 50 & 0 & 1033 \\
Mean \# eggs/g & 3 & 527 & 37 & 40 & 313 & 3 & 9280 \\
\% of total & 0.03 & 5.1 & 0.37 & 0.37 & 3.1 & 0.03 & 91.0 \\
\hline
\end{tabular}

1 Pig numbers refer to pigs $1-5$ listed in Table 1.

Table 3. Number of Schistosoma japonicum worm pairs recovered from Danish Landrace/Yorkshire pigs 11 weeks post-infection and various measurements of worm fecundity/worm pair.

\begin{tabular}{lcccc}
\hline Pig1 & $\begin{array}{c}\text { Number of } \\
\text { worm pairs }\end{array}$ & $\begin{array}{c}\text { Eggs/g rectal } \\
\text { tissue/worm pair }\end{array}$ & $\begin{array}{c}\text { Eggs/g liver } \\
\text { tissue/worm pair }\end{array}$ & $\begin{array}{c}\text { Eggs/g faeces/worm pair } \\
\text { (at maximum excretion) }\end{array}$ \\
\hline 1 & 9 & 2178 & 28 & 10 \\
2 & 6 & 14 & 83 & 16 \\
3 & 26 & 120 & 81 & 10 \\
4 & 21 & 1075 & 44 & 13 \\
5 & 25 & 413 & 19 & 10 \\
Mean & 17 & 760 & 51 & 10 \\
\hline
\end{tabular}

1 Pig numbers refer to pigs 1-5 listed in Table 1. 
biology of $S$. japonicum in the porcine host. The present study was undertaken to assess the suitability of Danish Landrace/Yorkshire crossbred pigs as experimental hosts for a Chinese mainland strain of $S$. japonicum.

\section{Materials and methods}

Ten male Landrace/Yorkshire crossbred piglets, initially 8-12 weeks of age and weighing $10-15 \mathrm{~kg}$, were used. The pigs were reared and housed indoors under specific pathogen-free conditions and were free from gastro-intestinal nematode infections. However, all pigs harboured infections with Balantidium coli throughout the experimental period.

A Chinese mainland strain of $S$. japonicum was used. The exposure to cercariae took place using the leg immersion technique with an exposure period of 30 min (van Wyk et al. 1975). Pigs were exposed to either $200(n=5), 500$ $(n=2)$ or $1000(n=3)$ cercariae each, and examination of faeces from week 5 onwards for eggs of $S$. japonicum was done using the modified Bell filtration method (Monrad et al. 1991). The pigs were euthanized and blood perfusion was performed after either 8 or 11 weeks using a modification of the technique described by Smithers \& Terry (1965). Schistosomes recovered were sexed and counted. Gross pathological lesions were noted at the time of perfusion, and $2 \mathrm{~g}$ samples were taken from the liver, duodenum, jejunum, caecum, colon, rectum and lung, respectively, for determination of tissue schistosome egg counts using the potassium hydroxide tissue digestion technique described by Bjørneboe \& Frandsen (1979).

\section{Results}

Infections with $S$. japonicum were established in all pigs, with faecal egg excretion starting week 6 after infection in 3 pigs and week 7 in the remaining 7 pigs (Table 1). Infections had a subclinical course in all animals. Faecal egg excre- tion in pigs followed beyond week 8 (Fig. 1) increased steadily until week 10 in all pigs. In 3 of 5 pigs, faecal egg excretion at week 11 remained comparable with that at week 10 , whereas in the remaining 2 pigs faecal egg excretion increased markedly from week 10 to week 11 . The highest value of $272 \mathrm{eggs} / \mathrm{g}$ faeces was observed week 11 in pig \#4 exposed to 500 cercariae (Fig. 1).

$S$. japonicum worm establishment varied greatly among the pigs, with recovery percentages ranging from $1.5 \%$ to $23.4 \%$ of the cercarial exposure dose (Table 1 ). In addition, the adult male:female worm ratio was quite variable, ranging from 8 to 0.6 .

Gross pathological lesions of varying degrees were seen in livers of all pigs at the time of perfusion. The lesions appeared as diffuse, white, pinpoint areas on the liver surface characteristic of schistosome egg granulomas (Fig. $2 \& 3$ ). These lesions were seen to coalesce in the more seriously affected livers giving them a greyish-white appearance. Macroscopic lesions of the intestinal tract were not observed. As appears in Table 2, most tissue-deposited $S$. japonicum eggs, as expressed by mean \# eggs/g tissue, were found in the rectum (91\%), with a moderate number of eggs also found in the liver $(5.1 \%)$ and caecum $(3.1 \%)$. Very few eggs $(<1 \%)$ were found in the duodenum, jejunum, colon and lungs, respectively. The tissue egg distribution pattern, as well as the total tissue egg counts/pig, differed markedly between pigs. Concerning fecundity measures, the number of eggs/g rectal tissue/worm pair was quite variable, being in the range of 14 to 2178 eggs/worm pair in the different pigs (Table 3). The number of eggs/g liver tissue/worm pair was less variable, being in the range of 19 to 83 eggs/worm pair. Faecal egg excretion (expressed as eggs/g faeces/worm pair) at the time of maximum excretion was comparable among 4 of the 5 pigs followed, with the figures ranging from 10 to 16 eggs/g faeces/worm pair. 


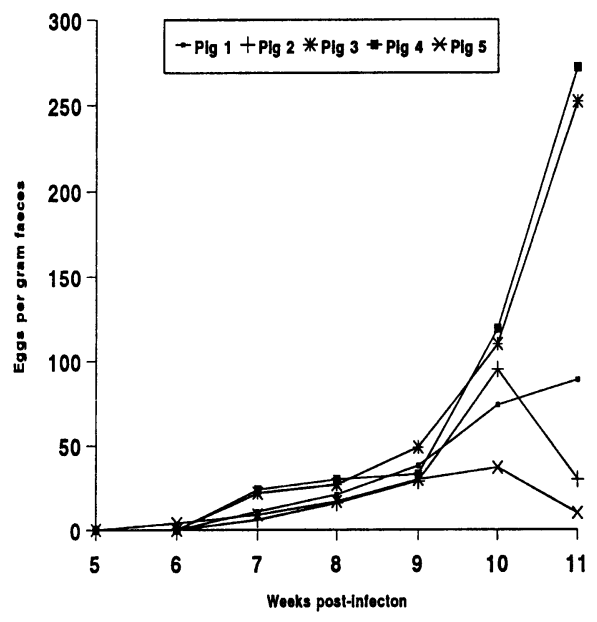

Figure 1. Number of Schistosoma japonicum eggs excreted per $\mathrm{g}$ faeces of individual Danish Landrace/Yorkshire crossbred pigs infected with 500 or 1000 cercariae during weeks 5 to 11 post-infection. (Note: Pig numbers refer to pigs 1-5 listed in Table 1).

\section{Discussion}

The present study shows that Danish Landrace/Yorkshire crossbred pigs are suitable experimental final hosts for the Chinese mainland strain of $S$. japonicum investigated. All pigs became infected, eggs were passed in their faeces and gross pathological lesions were noted in all of their livers. The length of the prepatent period, i.e. 6-7 weeks, exceeded that previously reported for the Philippine strain of $S$. japonicum, i.e. 4-5 weeks, and the worm recovery rate of 1.5 to $23.4 \%$ in the present study was in the lower range of the 18.9 to $30 \%$ recovery rate reported for the Philippine strain in pigs (Yason \& Novilla, 1984). In the latter study, the coverslip method of percutaneous exposure was used.

The variation in percentage worm establishment in the present study may be due to variations between pigs in susceptibility and response to $S$. japonicum infection, but variations in the biological characteristics of different batches of cercariae may also play a role. It is possible that the $S$. japonicum worm establishment may increase with less variability using other infection procedures such as the coverslip percutaneous method or various larva injection methods (James \& Taylor, 1976, Moloney \& Webbe, 1982, Yason \& Novilla, 1984). However, even following optimal infection procedures, a certain variation in worm establishment is to be anticipated.

Variations in total tissue egg counts, tissue egg counts per worm pair and the relative distribution of eggs of $S$. japonicum among different tissues were recorded. These variations may reflect differences in a given $S$. japonicum/pig relationship which can be affected by a range of different and sometimes interacting factors. However, the results leave no doubt that $S$. japonicum infection in pigs mainly affects the rectum and liver. This is similar to the human host (Mott 1982, Chen 1991), and supports the appropriateness of the pig as a model host for human schistosomiasis japonica.

Eggs of $S$. japonicum are deposited in clusters in vessels surrounding the intestinal tract where the schistosomes are located, whereas those in the liver are usually a result of embolization of eggs originally deposited in the intestinal vessels (Cheever \& Duvall, 1982). This needs to be considered in assessment of numbers and patterns of distribution of tissue deposited eggs.

The results show that the use of porcine schistosomiasis as a model for human schistosomiasis japonica has great merits. Further studies on the porcine schistosomiasis japonica model will address population biological and dynamical aspects of infection under the influence of variables such as exposure dose, number of exposures, duration of infection, and age and nutritional status of the pig host. Immunological, clinicopathological and histopathological studies will be added to ensure a full elucidation of central aspects of the $S$. japonicum/pig model. 


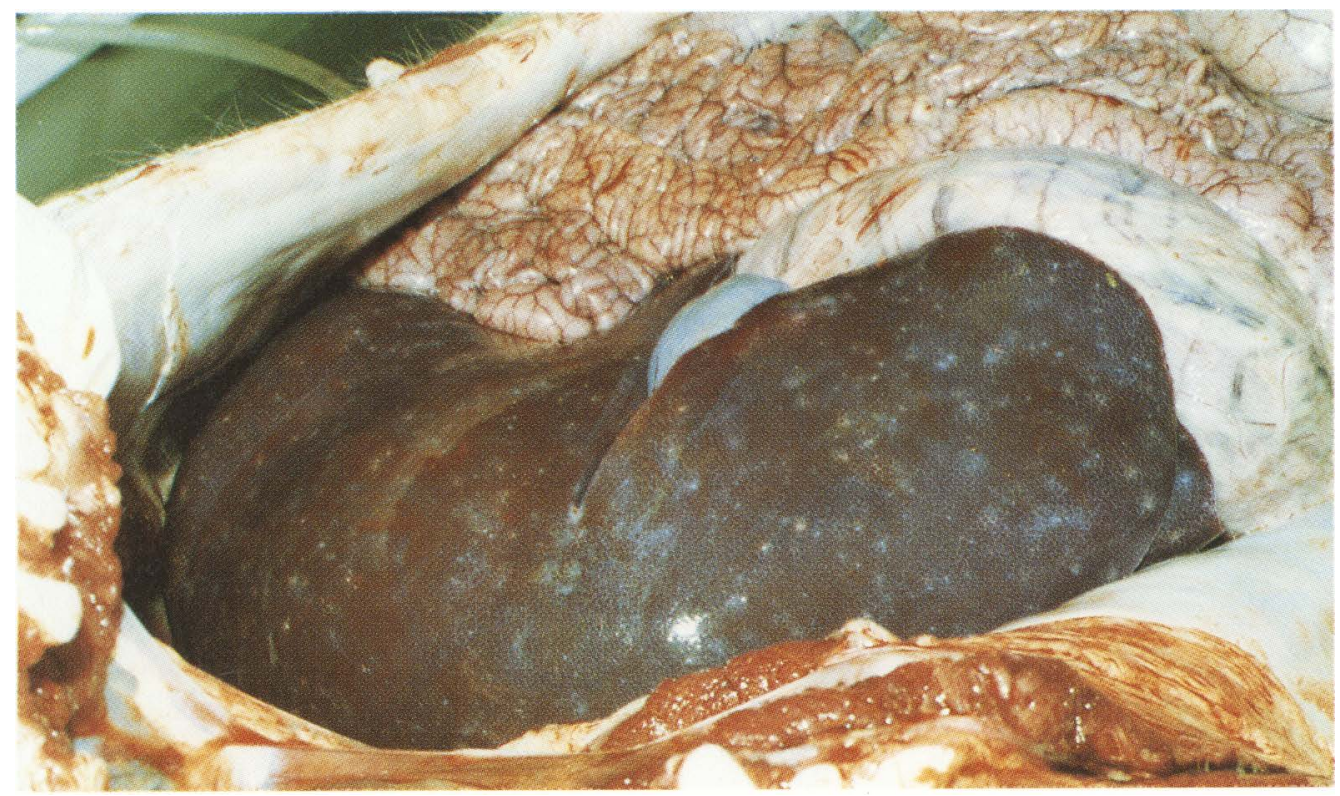

Figure 2. Liver of a Danish Landrace/Yorkshire crossbred pig 8 weeks after infection with 200 cercariae of Schistosoma japonicum.

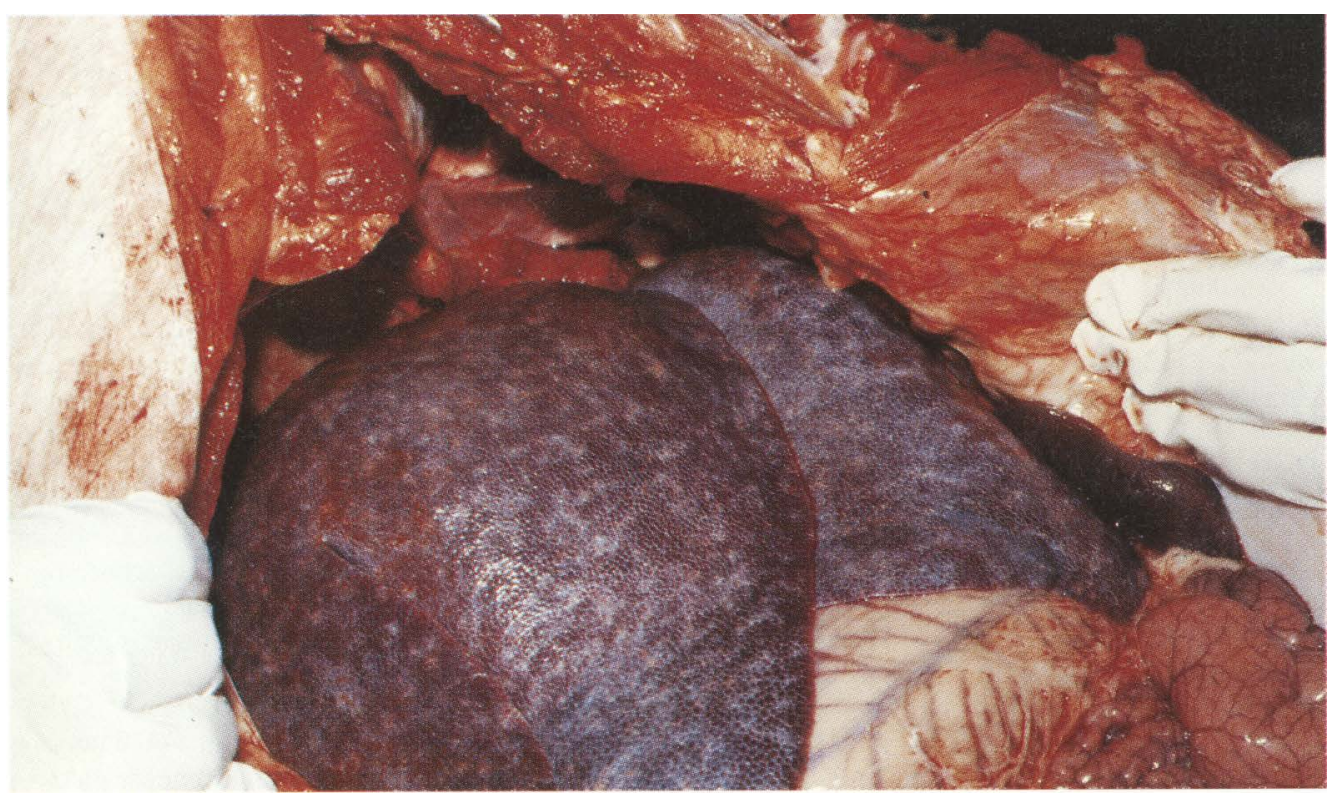

Figure 3. Liver of a Danish Landrace/Yorkshire crossbred pig 11 weeks after infection with 1000 cercariae of Schistosoma japonicum. 


\section{Acknowledgements}

The authors are grateful to Susanne Kronborg, Rasmus Turin, Pernille L. Strøm, Rasmus Nielsen, Niels Midtgaard, Annette Pedersen and Dr. Torsten Møller for technical assistance, and also to the staff of Sjaelland III pig station for animal care. The participation of Dr. Willingham was made possible by a graduate research grant from the Danish/American Fulbright Commission.

\section{References}

Basch PF: Schistosomiasis in China: An update. Amer. J. Chi. Med. 1986, 14, 17-25.

Bjørneboe A, Frandsen F: A comparison of the characteristics of two strains of Schistosoma intercalatum Fisher, 1934 in mice. J. Helminthol. 1979, 53, 195-203.

Cheever AW, Duvall RH: Schistosoma japonicum: Migration of adult worm pairs within the mesenteric veins of mice. Trans. R. Soc. Trop. Med. Hyg. 1982, 76, 641-645.

Chen MG: Relative distribution of Schistosoma japonicum eggs in the intestine of man: A subject of inconsistency. Acta Tropica 1991, 48, 163-171.

He YX: Biology of Schistosoma japonicum. Chi. Med. J. 1993, 106, 576-583.

James ER, Taylor MG: Transformation of cercariae to schistosomula: A quantitative comparison of transformation techniques and of infectivity by different injection routes of the organisms produced. J. Helminth. 1976, 50, 223-233.

Kumar V, de Burbure G: Schistosomes of Animals and Man in Asia. Helminth. Abstr. 1986, 55, 469-480.

Moloney NA, Webbe G: A rapid method for the infection of laboratory mice with Schistosoma japonicum. Trans. R. Soc. Trop. Med. Hyg. 1982, 76, 200-203.

Monrad J, Christensen $N \emptyset$, Nansen P: Acquired resistance in goats following a single primary Schistosoma bovis infection. Acta Tropica 1991, 48, 69-77.

Mott KE: $S$. japonicum and $S$. japonicum like infections. In: Schistosomiasis: Epidemiology, treatment and control. (Jordan P and Webbe G, eds.). William Heinemann Medical Books Ltd., London 1982, pp. 128-149.

Phillips RW, Tumbleson ME: Models. In: Swine in Biomedical Research (Tumbleson ME, ed) Plenum Press, New York 1986, pp. 437-440.

Reid WA, von Lichtenberg F: Experimental Schistosoma japonicum infection in miniature pigs. J. Parasitology 1977, 63, 392-394.
Shi YE, Jiang CF, Han JJ, Li YL, Ruppel A: Immunization of pigs against infection with Schistosoma japonicum using ultraviolet-attenuated cercariae. Parasitology 1993, 106, 459-462.

Smithers SR, Terry RJ: The infection of laboratory hosts with cercariae of Schistosoma mansoni and the recovery of the adult worms. Parasitology $1965,55,695-700$.

Swindle MM: Swine as a replacement for dogs in surgical teaching and research laboratories. Lab. An. Sci. 1984, 34, 383-385.

van Wyk JA, Heitmann LP, van Rensburg LJ: Studies on schistosomiasis. 7. A comparison of various methods for the infestation of sheep with Schistosoma mattheei. Onderstepoort J. Vet. Res. 1975, 42, 72-74.

Xu ST, Shi FH, Shen W, Lin JJ, Wang YH, Lin BF, Qian CG, Ye P, Fu LC, Shi YJ, Wu WJ, Zhang $Z D$, Zhu HJ, Guo WG: Vaccination of bovines against schistosomiasis japonica with cryopreserved-irradiated and freeze-thaw schistosomula. Vet. Parasitology 1993, 47, 37-50.

Yason CV, Novilla MN: Clinical and pathologic features of experimental Schistosoma japonicum infection in pigs. Vet. Parasitology 1984, 17, 47-64.

\section{Sammendrag \\ Eksperimentel infektion af Dansk Landrace/Yorkshire grise med Schistosoma japonicum fra den Kinesiske Folkerepublik.}

Egnetheden af Dansk Landrace/Yorkshire (L/Y) grise som eksperimentelle værter for et isolat af Schistosoma japonicum fra den Kinesiske Folkerepublik blev unders $\emptyset \mathrm{gt}$. Grise eksponeredes for 200, 500 eller 1000 cercarier, og bestemmelse af ormebyrdens størrelse fandt sted ved perfusion 8 eller 11 uger efter infektion. Alle grise inficeredes med fækal ægudskillelse startende 6 til 7 uger efter infektion. Det fækale ægudskillelsesmønster varierede markant mellem grisene. Makroskopiske, lever-patologiske læsioner af forskellig grad sås hos alle grise. Schistosomorme etableringen varierede mellem $1,5 \%$ og $23,4 \%$ af anvendte cercarier. De fleste schistosomæg, udtrykt som æg/gram væv, fandtes i rektum (91\%), med mindre forekomster i caecum $(3,1 \%)$ og lever $(5,1 \%)$. Unders $\varnothing$ gelsen viste at danske $\mathrm{L} / \mathrm{Y}$ grise kan fungere som velegnede eksperimentelle slutværter for det anvendte isolat af $S$. japonicum.

\section{(Received June 2, 1994; accepted September 5, 1994)}

Reprints may be requested from: A. Lee Willingham, Centre for Experimental Parasitology. Royal Veterinary and Agricultural University, Bülowsvej 13, DK-1870 Frederiksberg C, Denmark. 